\title{
Aracı Kurum Tavsiyelerinin Hisse Senedi Fiyatı Üzerindeki Etkisi: Türkiye Örneği
}

\author{
Leyla BEDELOVA* \\ Y1lmaz YILDIZ ${ }^{* *}$ \\ Mehmet Baha KARAN ${ }^{* * *}$
}

\section{ÖZET}

Çalışmanın amacı, hisse senetleri Borsa Istanbul'da işlem gören şirketlere yönelik aracı kurumların yaptığ tavsiyelerin hisse senedi fiyatı üzerindeki etkisini incelemektir. Mevcut çalışmanın hedeflerinden biri de söz konusu etki üzerinden piyasanın yarı güçlü formda etkin olup olmadığını ortaya koymaktır. Olay çalışması yöntemi kullanılarak yapılan analizde kısa vadede aracı kurumların hisse alım satımı ile ilgili tavsiyeleri ile hisse senedi fiyatlar arasında anlamlı bir ilişkinin olduğu, olay sonrası kısa vadede hisse senetlerinden anormal getiri elde edilebileceği tespit edilmiştir. Duyuru sonrası kısa vadede anormal getirilerin varlığl ve hisse senedi fiyatlarında duyurudan sonraki 15 günlük süre zarfinda herhangi bir geri dönüş yaşanmaması piyasanın yarı güçlü formda etkin olmadığını göstermektedir.

Anahtar Kelimeler: Piyasa etkinliği, aracı kurum tavsiyeleri, olay çalışması, anormal getiri.

JEL Sinıflandırması: C12, G11, G14.

\section{Impact of Brokerage Analysts' Recommendations on Stock Prices: Evidence from Turkey \\ ABSTRACT}

The purpose of this study is to examine the impact of analysts recommendations on the stock prices of the listed companies in Borsa Istanbul. Secondary aim of this study is to investigate whether the market is semi-strong form efficient. Using the event study analysis, it is revealed that there is a significant relationship between analysts' recommendations and stock prices in the short term and it is possible to earn abnormal returns in the postevent period. Existence of abnormal returns in the short term after the announcement and absence of any price reversals during the 15 days post-event period indicate that the market is not semi-strong form efficient.

Keywords: Market efficiency, analysts' recommendations, event study, abnormal return.

Jel Classification: C12, G11, G14.

\footnotetext{
* Leyla Bedelova, Hacettepe Üniversitesi, Sosyal Bilimler Enstitüsü, leylabedelova333@gmail.com

** Araş.Gör.Dr.Yılmaz Yıldız, Hacettepe Üniversitesi, İktisadi ve İdari Bilimler Fakültesi, yilmazyildiz@hacettepe.edu.tr

${ }^{* * *}$ Prof.Dr. Mehmet Baha Karan, Hacettepe Üniversitesi, İktisadi ve İdari Bilimler Fakültesi, mbkaran@hacettepe.edu.tr
} 


\section{GíRiș}

"Etkin piyasa" terimi, ilk olarak 1991 yılında Fama tarafından "piyasanın yeni bilgilere hızlı uyumu" şeklinde tanımlanmıştır (Fama, 1991). Eugene Fama'nın ortaya koyduğu Etkin Piyasalar Hipotezi (EPH) ise piyasa etkinliğini zayıf, yarı güçlü ve güçlü olarak üç aşamaya ayırarak piyasaların yarı güçlü etkin formda olduğu durumlarda hiçbir yatırımcının herhangi bir şekilde piyasa getirisinin üzerinde kazanamayacağını öne sürmüştür (Fama, 1991). Başka bir ifadeyle, EPH'ye göre yarı güçlü formda etkinlikte kamuya açıklanan bütün bilgilerin fiyatlara yansıdığı kabul edildiğinden, bu bilgiler kullanılarak yapılan herhangi bir hisse senedi analizi yoluyla işlem maliyetleri çıkarıldıktan sonra aşırı getiri elde edilmesinin mümkün olamayacağı ifade edilmektedir. Diğer taraftan, literatürde yapılan birçok çalışmalarda EPH`nin varsayımları birçok defa test edilmiş ve piyasaların birçok açıdan etkin olmadığı tespit edilmiş, bu bulgulara etkinlikten sapma anlamına gelen "anomali” adı verilmiştir.

Aracı kuruluşların yatırım önerileri özellikle kurumsal olmayan yatırımcıların hisse senedi seçiminde çok sık kullandıkları bir kaynaktır. Aracı kuruluşlar günümüze çoğunlukla internet siteleri vasıtası ile yatırımcılara belirli senetleri al veya sat tavsiyeleri vermektedir. $\mathrm{Bu}$ tavsiyeleri kullanan yatırımcıların işlemlerinde normalin üzerinde bir getiri elde edilebileceği umulmaktadır. Ancak EPH'ye göre bu tavsiyeler etkin olmayan veya zayıf formda etkin piyasalarda geçerlidir. Pazarlar yarı kuvvetli formda etkin olmaya başladıklarında, yatırım tavsiyelerinin hiçbir ekonomik katkısı olmaması gerekmektedir. Bu nedenle birçok bilimsel çalışmada aracı kurumu tavsiyeleri yarı güçlü formda piyasa etkinliğinin test edilmesinde kullanılmaktadır. İkinci bölümde daha detaylı olarak inceleneceği üzere literatürde yapılan birçok çalışmada (Groth vd., 1979; Bjerring vd. 1983; Womack, 1996; Barber vd. 2001; Jegadeesh ve Kim 2006; Lim ve Kong, 2004; Moshirian vd. 2009) arac1 kurum tavsiyelerinin hisse senedi fiyatları üzerinde etkili olduğu tespit edilmiştir. Türkiye borsası ile ilgili olarak yapılan çalışmaların sayısı oldukça kısıtlıdır. Karan ve Ressamoğlu (1996) ve Yazıcı ve Muradoğlu, (2002) yaptıkları çalışmarda haftalık bir dergide çıkan aracı kurumlara ait tavsiyeler ile yatırım performansı ilişkisini incelenmiştir. Ancak son yıllarda Türkiye ile ilgili herhangi bir çalışmaya rastlanmamıştır.

Bu çalışmada Türkiye'nin en büyük aracı kurumlarından biri olan İş Yatırım şirketinin internet sayfasından temin edilen tavsiyeler kullanılarak 2007-2015 y1lları arasında yapılan duyurular ele alınarak aracı kurum tavsiyelerinin hisse senedi fiyatları üzerindeki etkisi olay çalışması kullanılarak incelenmiştir. Çalışmanın amacı aracı kurumların hisse senetlerine yönelik verdikleri tavsiyelerin bu hisse senetlerinin fiyatlarına kısa vadede bir etkisinin olup olmadığını belirlemektir.

Çalışmanın temel hipotezi Borsa İstanbul'un yarı güçlü formda etkin olmadığı yani yatırım tavsiyelerinin hisse senedi fiyatları üzerinde etkili olduğudur. Alt hipotezler olarak dördüncü bölümde detaylı bir şekilde açıklandığı üzere 4 ayrı hipotez 
oluşturulmuştur. Borsa İstanbul son beş yll içinde büyüyen işlem hacmi ve artan halka açık şirket sayısı ile gelişmekte ve büyümekte olan önemli bir borsadır. Son yıllarda halka açı şirketlerin hisse senetlerinin yaklaşık \%65-70'inin yabancı yatırımcılar tarafından alınmış olması piyasaya uluslararası güvenin artması piyasa etkinliğinin tekrar ele alınmasını gerekli hale getirmektedir. Bu çalışmada ele alınan 2007-2015 dönemi güncel bir zaman periyodunu ele alması açısından çalışmanın amacı ve literatüre katkısı ile örtüşmektedir.

$\mathrm{Bu}$ çalışma altı bölümden oluşmaktadır. İkinci bölümde literatürde yer alan diğer çalışmalardan bahsedilirken, üçüncü bölümde çalışmanın veri seti ve kullanılan yöntem açıklanmaktadır. Çalışmada ele alınan hipotezlerin anlatıldığı dördüncü bölümden sonra çalışmadan elde edilen bulgular beşinci bölümde tartışılmaktadır. Altıncı ve son bölüm genel bir değerlendirme içermektedir.

\section{ARACI KURUM TAVSIYYELERINIIN HISSE SENEDİ FIYATLARINA ETKISII ÜZERINE YAPILAN ÇALIŞMALAR}

Fama ve birçok bilim adamının EPH konusunda yaptı̆̆ çalışmaları takip eden çok sayıda çalışma ile piyasaların etkinliği test edilmeye başlanmıştır. Bunların içinde özellikle aracı kuruluşların tavsiyelerinin hisse senedi fiyatları üzerine etkisi de literatürde önemli bir yer almaktadır.

Aracı kurum tavsiyelerinin hisse senedi fiyatlarına etkisi üzerine yapılan ilk çalışmalardan biri Davies ve Canes (1978)'e aittir. 1971 ve 1972 yılları arasında 597 "al" ve 188 "sat" tavsiyesinin hisse senedi fiyatları üzerindeki etkisini inceleyen çalışmadan elde edilen bulgular aracı kurum tavsiyelerinin hisse senedi fiyatları üzerinde önemli bir etkiye sahip olduğunu göstermektedir. Hisse senedi fiyatlarının tavsiye sonrası 20 günlük sürede eski fiyat aralığına geri dönüş yapmaması yatırım tavsiyelerinin hisse senetleri ile ilgili önemli bilgi içerdiği ve bu etkinin kalıcı sonuçlara neden olduğu şeklinde yorumlanmıştır. Yatırım tavsiyeleri ile ilgili yapılan diğer bir çalışmada ise, Groth vd. (1979) 1964-1970 yılları arasında ilan edilen yatırım tavsiyelerini incelemiştir. Çalışma sonucunda özellikle "al" tavsiyelerinin hisse senedi getirileri üzerinde önemli etki yaptığı tespit edilmiştir. Tavsiye sonrası ilk ay boyunca tavsiye edilen hisse senetlerinden pozitif anormal getiri elde edilebileceği, daha sonraki dönemde ise anormal getirilerin sıfira yaklaştığ görülmüş̧ür. 1977-1981 yılları arasını kapsayan ve Kanada ve ABD borsasına kote şirketleri içeren bir diğer çalışmada ise Bjerring vd. (1983) birçok farklı yöntem kullanarak yatırım tavsiyelerinin hisse senedi fiyatları üzerindeki etkisini incelemişlerdir. Elde edilen sonuçlar aracı kurum tavsiyelerine yapılan yatırım sonucunda beklenenin üzerinde getiri elde edilebileceği yönündedir.

Literatürde yapılan birçok çalışma "Wall Street Journal”"da yayınlanan yatırım önerileri üzerine odaklanmıştır. Albert Jr. ve Smaby (1996) “Wall Street Journal”"In Dartboard köşesinde 1988-1991 yılları arasında ilan edilen 156 yatııım tavsiyesi incelemiştir. Tavsiye edilen hisse senetlerinin ilan sonrası normalüstü getiri elde ettiği 
ve tavsiye sonrası hisse senetlerinin yeni fiyat dengesine ulaştığı görülmüştür. Bu sonuç, yatırım tavsiyelerinin kısa süreli fiyat hareketlerinden çok uzun vadeli etkilere sahip olduğunu göstermektedir. Başka bir ifadeyle, yatırım tavsiyeleri yatırımcılar için önemli bilgiler içermektedir. ABD borsalarını içeren bir diğer çalışmada Womack (1996) 1573 yatırım tavsiyesinin hisse senedi fiyatları ve işlem hacmi üzerindeki etkisini incelemiştir. Çalışma sonucunda yatırımcıların yatırım tavsiyelerini dikkate almaları durumunda hem kısa hem de uzun vadede normalüstü getiri elde edebileceği tespit edilmiştir. Bu sonuç, analistlerin hisse senedi seçimi konusunda başarılı olduklarının bir göstergesidir. Barber vd. (2001) 1985-1996 yılları arasında NYSE, AMEX ve NASDAQ borsalarında işlem gören hisse senetlerini içeren çalışmasında yatırımcıların günlük bir şekilde yatırım tavsiyelerini dikkate almaları durumunda yıllık yaklaşık \%4 normalüstü getiri elde edebileceklerini tespit etmişlerdir. Bu sonuç, piyasaların yarıgüçlü formda etkin olmadığının bir göstergesidir. Moshirian vd. (2009) bu çalışmalardan farklı olarak, yatırım tavsiyelerini 13 gelişmekte olan ülkeyi kapsayacak şekilde incelemişlerdir. Her ne kadar farklı ülkeler için farklı sonuçlar elde edilse de, genel olarak yatırım tavsiyelerinin kısa ve uzun vadede normalüstü getirilere yol açtığı tespit edilmiştir. Çalışmada ayrıca normal üstü getirilere neden olabileceği düşünülen firmaya özgü faktörler de analize dahil edilmiş ve özellikle "al” tavsiyelerinin firmaların Piyasa Değeri/Defter Değeri'nden etkilendiği belirlenmiştir.

Literatürde yapılan önemli sayıda çalışmada ise, yukarıda özetlenen bulguların aksine yatırım tavsiyelerinin hisse senedi fiyatları üzerinde etkili olduğu ancak bu etkinin fiyat baskısından kaynaklı olup, uzun vadede fiyatların normal seviyelerine geri dönecekleri tespit edilmiştir. Başka bir ifadeyle, bu çalışmalar her ne kadar kısa süreli fiyat hareketleri görülse de yatırım tavsiyelerinin bilgi içeriğinin zayıf olduğunu ve yatırımcıların uzun vadede bu tavsiyeler yardımıyla normalüstü getiri elde edemeyeceğini tespit etmişlerdir. Barber ve Loeffler (1993) yatırım tavsiyelerinin hisse senedi getirileri üzerindeki etkisini 1988-1990 yılları arasında Wall Street Journal'ın Dartboard köşesinde yer alan tavsiyeleri temel alarak incelemişlerdir. Tavsiyeyi takip eden iki gün içerisinde pozitif anormal getirilerin gözlendiği çalışmadan elde edilen sonuçlar hisse senedi fiyatlarının hem tavsiyelerin bilgi içeriğinden hem de kısa vadede oluşan fiyat baskısından etkilendiğini göstermektedir. Kerl ve Walter (2007)'in Alman borsasında yaptıkları analizler de Barber ve Loeffler (1993)'ün sonuçlarını desteklemektedir. Desai ve Jain (1995) 1968-1991 yılları arasında Barron's da yayınlanan 1751 yatırım tavsiyesinin hisse senedi fiyatları üzerindeki etkisini incelemiş, tavsiye tarihi ile yayınlanma tarihi arasında geçen 14 günlük sürede "al" tavsiyesi verilen hisse senetlerinin \%1,91 normalüstü getiri elde ettiği görülmüştür. Ancak yayınlanma tarihi sonrası 3 yıllık süre ele alındığında anormal getirilerin sıfıra yakın olduğu ve yatırımcıların bu tavsiyeler yoluyla uzun vadede normalüstü getiri elde edemeyeceği tespit edilmiştir. Desai ve Jain'e benzer şekilde Sant ve Zaman (1996) Business Week'te yer alan yatırım tavsiyeleri üzerine yaptıkları çalışmada olumlu olarak 
nitelendirilen hisse senetlerinin tavsiye sonrası kısa vadede normalüstü getiri elde ettikleri ancak 6 aylık sürede bu getirilerin ortadan kalktığı görülmüş̧ür. Albert Jr. ve Smaby (1996) ve Barber ve Loeffler (1993)'in çalışmalarına benzer şekilde Liang (1999) 1990-1994 dönemleri arasında Wall Street Journal'ın Dartboard köşesinde tavsiye edilen hisse senetlerinin kısa ve uzun vadeli performanslarını incelemiştir. Elde edilen sonuçlar duyuru tarihi itibariyle 2 günlük süre içerisinde yatırımcıların normalüstü getiri elde edebileceğini ancak 15 günlük sürede hisse senedi fiyatlarının tavsiye öncesi değerlerine geri döndüğü tespit edilmiştir. Bu sonuç, hisse senedi fiyatlarının tavsiyelerin bilgi içeriğinden çok olay günü oluşan fiyat baskısından etkilendiğini göstermektedir. Çalışmadan elde edilen diğer bir sonuç da 6 aylık sürede tavsiye edilen yatırımların yaklaşı \%3,6 değer kaybı yaşadığıdır. Liden (2004)'ün İsveç borsası üzerinde yaptığı analizler de yatırım tavsiyelerinin kısa vadede fiyat baskısı nedeni ile normalüstü getirilere neden olduğunu desteklemektedir.

Literatürde yatırım tavsiyelerinin hisse senedi fiyatları üzerinde herhangi bir etkisinin olmadığını raporlayan çalışmalar da mevcuttur. Metrick (1999) ve Dewally (2003)'nin çalışmalarından elde edilen sonuçlar yatırım tavsiyeleri ile normalüstü getiriler arasında kısa ya da uzun vadeli herhangi bir ilişkinin olmadığını göstermektedir.

Ülkemizde bu konuda yapılan yalnız iki çalışmaya ulaşılmıştır. Bunlardan ilki Karan ve Ressamoğlu (1996) tarafindan gerçekleştirilmiştir. Çalışmanın temel amacı yatırımcıların haftalık dergilerde yayınlanan tavsiyeler doğrultusunda yatırım kararı verip vermediğini araştırmak ve bu dergilerdeki tavsiyelere göre hisse senedi alındığında normalüstü getiri elde edilip edilemediğini belirlemektir. $\mathrm{Bu}$ amaçla yatırımcılara yönelik anket çalışması yapılmış, ayrıca ekonometrik modeller yoluyla uzman görüşlerinin hisse senedi fiyatları üzerindeki etkisi Ekonomist dergisinin uzman tahminleri köşesindeki tahminler temel alınarak Ocak 1993 - Aralık 1994 tarihleri arasında değerlendirilmiştir. Elde edilen bulgulara göre, hisse senedi tavsiyeleri fiyat üzerinde herhangi bir etkiye sahip değildir. Sonuç itibariyle uzman tavsiyeleri doğrultusunda hareket eden yatırımcılar normalüstü getiri elde edememektedir.

Türkiye'de gerçekleştirilen diğer bir çalışma da Yazıcı ve Muradoğlu (2002) tarafından gerçekleştirilmiştir. Bu çalışmada da 1993-1998 döneminde Paramatik dergisinde çıkan aracı kurum uzmanlarının hisse senedi alım tavsiyelerinin etkileri incelenmiştir. Elde edilen sonuçlara göre her ne kadar kısa vadede önerilen hisselerin yatırımcılara normalüstü getiriler sağladığı tespit edilmişse de, bu etkinin uzun vadede geçerli olmadığı görülmüştür. İşlem maliyetleri çıkarıldıktan sonra yatırımcılar uzman tavsiyelerini dikkate alarak yaptıkları yatırım sonucunda herhangi bir normalüstü getiri elde edememektedirler. Ancak bu bilgilere dergi basılmadan birkaç gün önce ulaşan yatırımcıların haftalık $\% 5$, ve yıllık $\% 1500$ gibi çok yüksek bir oranda normal üstü getiri elde edebilecekleri anlaşılmıştır. 


\section{VERI SETİ VE YÖNTEM}

$\mathrm{Bu}$ çalışmada Borsa İstanbul'da yer alan hisse senetlerine yönelik İş yatırım internet sitesinde borsa uzmanları tarafindan 2007-2015 y1lları arasında yapılan hisse senedi tavsiyelerinin hisse senedi fiyatları üzerindeki etkisi incelenmektedir. Bir önceki bölümde detaylı olarak ele alındığı üzere, yakın zamanda aracı kurum önerilerinin hisse senedi fiyatlarına olan etkisi üzerine bir çalışma bulunmamaktadır. Özellikle 2008 finansal krizi ve sonrasını içeren bir çalışma borsasının etkinliğinin tekrar değerlendirilmesi açısından önemlidir. Çalışmada aracı kurum tavsiyelerinin hisse senedi getirilerini ne yönde etkileyeceği olay çalışması yöntemiyle analiz edilmiştir. Yöntemle ilgili detaylı bilgi bir sonraki bölümde ele alınmaktadır. Çalışma kapsamında yer alan şirketlerin hisse senetlerine ait fiyat bilgisi DataStream veri tabanından alınmıştır. Aracı kurum tavsiyeleri ise İş Yatırım'ın resmi internet sitesinde yer alan haftalık raporlardan temin edilmiştir. Çalışmada üzerinde durulması gereken bir nokta da yatırım tavsiyelerinin sahip olduğu farklı özelliklerdir. Literatürde yapılan birçok çalışmada yatırım tavsiyeleri al ya da sat olarak nitelendirilmiş ve bu tavsiyelerin fiyatlar üzerindeki etkisi incelenmiştir. Ancak bu çalışma tavsiyelerin niteliği yönünden diğer çalışmalardan ayrışmaktadır. İş Yatırım, haftalık olarak güncelenen yatırım raporlarında al-sat önerilerine ek olarak 2 ayrı başlık altında "Önerilenler" ve “Önerilmeyenler” olarak hisse senetlerini gruplandırmaktadır. Yatırım şirketi, gelecekte kendisinden çok yüksek ya da düşük performans beklenilen hisse senetleri için daha detaylı bilgiler sunmakta ve periyoduk olarak bu listeleri güncellemektedir. Başka bir ifadeyle, bu iki liste yatırım şirketinin diğer al-sat önerilerine ek olarak şirketlerle ilgili daha detaylı bilgilerin sunulduğu, özel olarak izlenen ve yatırım şirketinin en fazla güvendiği tavsiyelerin dahil edildiği listelerdir. Bu yönüyle çalışma, literatürdeki benzer çalışmalardan ayrışmaktadır.

Çalışmanın uygulama kısmında öncelikli olarak, aracı kurumların yaptığ tavsiyelerin yayınlandığı günün 15 gün öncesi ve 15 gün sonrasını kapsayan günlük normalüstü getiriler hesaplanmıştır. Toplam gözlem periyodu duyurunun yapıldığı gün de dahil edildiğinde 31 gündür. Sürenin olay tarihinden 15 gün önce ve 15 gün sonra seçilmesi ile hisse senedi getirilerinin olaya duyarlılığının daha sağlıklı biçimde ölçmek amaçlanmıştır (Liang, 1999). Olay penceresinin gerekenden uzun seçilmesi çalışmanın gücünü zayıflatmakta ve olayın anlamlılığı hakkında yanlış değerlendirmelere yol açabilmektedir. Ayrıca, yatırım şirketi tavsiye edilen hisse senetlerinin uzun vadeli performansını haftalık ve yıllık raporlarında düzenli olarak değerlendirmektedir. Başka bir ifadeyle, bu çalışmanın temel amacı kısa vadede yatırım tavsiyelerinin hisse senedi fiyatları üzerindeki etkilerini açıklamak ve piyasanın kısa vadede yatırım tavsiyelerine verdiği tepkiyi inceleyerek piyasa etkinliğini tartışmaktır. $\mathrm{Bu}$ nedenle, halihazırda yatırım raporlarında yer alan uzun vadeli performans değerlendirmesi çalışmanın kapsamı dışında bırakılmıştır. 
Bu çalışmada olay çalışması yöntemi ile yatırım tavsiyelerinin hisse senedi fiyatı üzerindeki etkisi incelenmiştir. Olay çalışması yöntemi bir olay gerçekleştiğinde piyasanın bu olaya verdiği olağandışı tepkiyi ölçmede kullanılan bir yaklaşımdır. Diğer bir ifade ile olay çalışması, herhangi bir olayın hisse senedinin performansını uzun veya kısa dönemde artırdığı veya artırmadığı konusunda sonuçlar çıkarılmasını sağlayan ve piyasanın etkinliğini ölçmede kullanılan ekonometrik bir yöntemdir. Normalüstü ya da anormal getiriler olay çalışmalarının çıkış noktasını oluşturmaktadır.

Olay çalışmalarında en kritik noktalardan biri olay penceresinin belirlenmesidir. Literatürde yapılan çalışmalar dikkate alındığında yatırım tavsiyelerinin hisse senedi fiyatları üzerindeki etkisi farklı olay pencereleri dikkate alınarak incelenmiştir. Olay penceresinin uzun seçilmesi istatistiksel olarak çalışmanın gücünü azaltabilmekte ve olayın anlamlılığı hakkında yanlış değerlendirmelere neden olabilmektedir (Kothari ve Warner, 2004). Buna karşın olay penceresinin kısa seçilmesi ise elde edilen sonuçların daha güvenilir olmasını sağlamaktadır (Antweiler ve Frank, 2006). Bu çalışmada incelemeye konu olan olay aracı kurum tavsiyeleri, olayın gerçekleşme zamanı bu tavsiyelerin duyurulduğu tarih (gün), olay penceresi ise önerilerin duyurulduğu tarihin 15 gün öncesi ve 15 gün sonrası olarak belirlenmiştir. Literatürde yapılan diğer çalışmalar dikkate alındığında olay penceresinin çok daha uzun (3 yıla kadar) belirlendiği çalışmalar görmek de mümkündür. Ancak, uzman tahminlerinin ele alındığ 1 İş Yatırım şirketi kendi önerilerinin yatırım performansını uzun vadeli değerlendirmekte ve performans analizlerine yatırım raporlarında yer vermektedir. Başka bir ifadeyle İş Yatırım şirketinin portföy performansı haftalık ve yıllık raporlarda detaylı bir şekilde yer almaktadır. Bu nedenle bu çalışmada daha kısa bir olay periyodu tercih edilerek, uzman tavsiyelerinin kısa süreli etkisi değerlendirilmektedir.

Sonuç itibariyle olay çalışmasının amacı, bir olayın piyasaya ilk duyurulduğu tarih etrafında normalüstü getiri sağlayıp sağlamadığını tespit etmektir. Normalüstü getiriler, önerilerin yayınlanmadığı veya haberlerin duyurulmadığı anda olan normal getirilerden düşük veya yüksek olan getirilerdir ve "anormal getiriler" olarak da ifade edilmektedir.

Matematiksel olarak hisse senetlerinin anormal getirileri aşağıdaki gibi hesaplanmıştır (Yazıcı ve Muradoğlu, 2002):

$$
A G_{i, t}=G_{i, t}+G_{m, t}
$$

Formüldeki $A G_{i, t}$ i hisse senedi için $\mathrm{t}$ günündeki olağandışı veya anormal getiriyi, $G_{i, t}$ i hisse senedinin t günündeki getirisini, $G_{m, t} \mathrm{t}$ günündeki pazar getirisini ifade etmektedir.

İkinci aşamada, her hisse senedi için ilgili günde elde edilen anormal getiriler toplanıp, hisse senedi sayısına bölünerek ortalama anormal getiri (OAG) elde edilmiştir. 


$$
O A G_{t}=\frac{1}{N} \sum_{t=1}^{N} A G_{i, t}
$$

Son aşamada ise $\mathrm{t}$ zamandaki ortalama kümülatif anormal getiriler (OKAG) şu şekilde elde edilmiştir:

$$
O K A G_{t}=\sum_{t=1}^{T} O A G_{t}
$$

Çalışmada ortalama anormal getiri $(\mathrm{OAG})$ ve ortalama kümülatif anormal getirilerin (OKAG) istatistiksel olarak sıfırdan farklı olup olmadığını test etmek için birçok çalışmada olduğu gibi t değeri şu şekilde hesaplanmıştır:

$$
t_{\text {OKAG }}=\frac{K A G_{t}}{\left(\sigma K A G_{t}\right) / \sqrt{n}}
$$

Formüldeki $O A G_{t}$ t zamandaki kümülatif anormal getiriyi, $\sigma O A G_{t}$ ortalama anormal getirilerin standart sapmasını, $\mathrm{n}$ ise örneklem sayısını ifade etmektedir. Anormal ve kümülatif anormal getirilerin anlamlılık değerlerine ek olarak çalışmada her gün için anormal getirisi sıfırdan büyük ya da küçük olan gözlem sayısı hesaplanmış ${ }^{1}$ ve toplam gözlem sayısına bölünerek o gün için ortalama pozitif ya da negatif gözlem sayısının toplam gözlem sayısına oranı hesaplanmıştır. Daha sonra bu oranların (oranların) z değerleri yoluyla istatistiksel olarak 0,5 'ten farklı olup olmadığ 1 test edilmiştir. Bu testin yapılmasındaki amaç sonuçların güvenirliğinin sağlanmasıdır. Aksi takdirde, uç değerler nedeniyle anormal getiriler olması gerekenden büyük ya da küçük olabilecek ve analiz sonuçlarını olumsuz etkileyebilecektir. Z değeri şu şekilde hesaplanmıştır.

$$
z=\frac{p-0,5}{\sqrt{p q / n}}
$$

Eşitlikteki p, anormal getirisi sıfırdan büyük ya da küçük olan örneklem sayısının toplam örneklem sayısına oranını, q ise 1-p değerini ifade etmektedir. Son olarak n örneklem sayısına karşılık gelmektedir.

\section{HIPPOTEZLERIN OLUŞTURULMASI}

İş yatırım uzmanlarının yaptıkları yatırım tavsiyeleri "önerilen" ve “önerilmeyen” hisse senetleri olmak üzere 2 ana başlık altında gruplanmıştır. Her hafta açıklanan raporla birlikte, bazı hisseler öneri listesine dahil olurken bazı hisseler de bu listeden çıkarılmıştır. Aynı raporda ele alınan diğer bir başlık da önerilmeyen hisse

\footnotetext{
${ }^{1}$ Önerilen hisse senedi listesine dahil edilen ve önerilmeyen hisse senetleri listesinden çıartılan hisse senetlerinde anormal getirisi slfirdan büyük olan örneklem sayısının toplam örneklem sayısına oranı hesaplanırken; önerilen hisse senedi listesinden çıkartılan ve önerilmeyen hisse senetleri listesine eklenen hisse senetleri için anormal getirisi sıfirdan küçük olan örneklem sayısının toplam örneklem sayısına oranı hesaplanmıştır. Z değerleri bu oranları dikkate alınarak hesaplanmıştır.
} 
senetleridir. Gelecek performansı olumsuz olarak görülen hisse senetleri bu listeye dahil edilirken, daha önce bu listeye eklenen bazı hisse senetleri ise olumsuz durumun ortadan kalkması sonucunda bu listeden çıkarılmıştır. Bu doğrultuda, bu listelere eklenen ya da çıkan hisse senetlerindeki fiyat hareketliğinin incelenmesi bu çalışmanın temel amacını oluşturmaktadır. Sonuç olarak, yatırım tavsiyesi içeren 4 farklı hisse senedi grubu şu şekilde özetlenebilir:

a. Öneri listesine eklenen hisse senetleri

b. Öneri listesinden çıkan hisse senetleri

c. Önerilmeyen listesine eklenen hisse senetleri

d. Önerilmeyen listesinden çıkan hisse senetleri

Çalışmanın veri seti, Eylül 2007 - Nisan 2015 döneminde BİST'de işlem gören şirketlerin hisse senetlerine yönelik aracı kurumun yaptığı öneri ve tavsiyelere göre toplam 299 önerilen ve önerilmeyen hisse senedini kapsamaktadır. Bu öneri ve tavsiyelere göre 127 hisse senedi öneri listesine eklenmiş, 116 hisse senedi öneri listesinden çıkarılmış, 26 `sı önerilmeyen listesinden çıarılmış ve 30`u da önerilmeyen hisse senetleri listesine dahil edilmiştir. Önerilmeyen hisse senedi listesi 2009 yllından itibaren oluşturulmaya başlanmıştır. $\mathrm{Bu}$ nedenle, bu grupta yer alan gözlem sayısı önerilen hisse senedi listesine oranla daha azdır.

$\mathrm{Bu}$ çalışmanın temel amacı aracı kurum tavsiyelerinin kısa vadede hisse senedi fiyatları üzerindeki etkisini inceleyerek piyasasının yarı güçlü formda etkin olup olmadığını irdelemektedir. Bu amaç doğrultusunda oluşturulan dört ayrı hipotez aşağıda detaylı bir şekilde açıklanmaktadır.

Çalışmanın ilk hipotezi, yatııımcıların öneri listesine dahil edilen şirketlere ait hisse senetlerine yaptığı yatırımlardan aşırı getiri elde etmeleri ile ilgilidir. Yatırımcılar yatırım tavsiyelerine olumlu yaklaşarak onların önerdiği hisse senetlerini alma ve önermediklerini ise satma eğilimi içerisindedirler. Literatür bölümünde detaylı olarak ele alındığı üzere yapılan birçok çalışmada olumlu yatırım önerilerinin hisse senedi fiyatlarında kısa ve hatta uzun vadeli normalüstü getirilere neden olduğu tespit edilmiştir. Bu sonuç, yatırım önerilerinin bilgi içeriğinden kaynaklı olabileceği gibi özellikle kısa süreli fiyat hareketleri için fiyat baskısı yoluyla da normalüstü getiriler elde edilebileceğini göstermektedir. Bu beklentiler doğrultusunda ilk hipotez şu şekilde oluşturulmuştur.

$\mathbf{H}_{\mathbf{1}}$ : Aracı kurum öneri listesine dahil edilen şirketlere ait hisse senedi fiyatlarında duyuru sonrası anormal artış yaşanır.

Çalışmada ele alınan ikinci hipotez, listeden çıkarılan şirketlere ait hisse senetlerinin bu duyurulardan negatif etkilendiği yönündedir. Uzman değerlendirmeleri sonucu herhangi bir olumsuzluktan kaynaklanarak bu şirketler öneri listesinden çıarılmıştır. Aracı kurumların tavsiyelerini dikkate alan yatırımcıların listeden çıkarılan 
hisse senetlerini satma eğiliminde oldukları düşünüldüğünde mevcut hisselerin fiyatında düşüş gerçekleşmesi beklenmektedir. Buna göre hipotez şu şekilde oluşturulmuştur:

$\mathbf{H}_{2}$ : Aracı kurum öneri listesinden çıkarılan şirketlere ait hisse senedi fiyatlarında duyuru sonrası anormal düşüş yaşanır.

2009 y1lı itibariyle İş Yatırım tarafından önerilen hisse senedi listesine ek olarak önerilmeyen hisse senedi listesi de oluşturulmaya başlanmıştır. Bu listeye eklenen hisse senetleri ile ilgili olarak $\mathrm{H}_{2}$ hipotezinde olduğu gibi hisse senedi fiyatlarında olay sonrası anormal düşüş yaşanması beklenmektedir. Başka bir ifadeyle, her ne kadar önerilen listesinden çıkartılmak ile önerilmeyen hisse senetleri listesine dahil edilmek farklı olaylar olsa da, iki duyurunun da olumsuz nitelik taşımasından dolayı piyasanın bu iki duyuruya benzer tepki göstereceği beklenmektedir. Bu doğrultuda hipotez şu şekilde oluşturulmuştur:

$\mathbf{H}_{3}$ : Aracı kurum önerilmeyen hisse senetleri listesine dahil edilen şirketlerin duyuru sonrası hisse senedi fiyatlarında anormal düşüş yaşanır.

Aracı kurumların bazı şirketlerin isimlerini önerilmeyen listeden çıkarmak yönünde yaptığı duyurular yatırımcılar tarafından pozitif değerlendirildiğinde bu şirketlerin hisse senetlerine ilgi artabilir. Ayrıca, şirket ile ilgili olumsuz durum giderildiğinden bu şirketler önerilmeyen hisse senedi listesinde artık yer almamaktadır ve bu durum mevcut hisselerin fiyatında artışa neden olabilecektir. Bu doğrultuda önerilmeyen hisse senedi listesinden çıkan şirketlerle ilgili hipotez şu şekilde oluşturulmuştur:

$\mathbf{H}_{4}$ : Aracı kurum önerilmeyen hisse senedi listesinden çıkarılan şirketlerin duyuru sonrası hisse senedi fiyatlarında anormal artış yaşanır.

\section{BULGULAR}

Tablo 1'de öneri listesine eklenen hisse senetleri ile ilgili sonuçlar yer almaktadır. Öneri listesine eklenen hisse senetleri olay günü yaklaşık \%1,45 ortalama anormal getiri elde etmektedir. Elde edilen sonuç \%1 seviyesinde anlamlıdır. Olay günü sonrası $(+1 \mathrm{ve}+2)$ da piyasanın yatırım tavsiyesine olumlu tepkisi devam etmektedir. 3 günlük $(0,+1$ ve +2$)$ kümülatif anormal getiri ise yaklaşık olarak $\% 2,88$ seviyesindedir. Olay sonrası 2. günden sonra piyasa tepkisi normal seviyelere ulaşsa da, 15 günlük olay penceresinde fiyatlarda olay öncesi seviyeye dönüş gözlenmemiştir. Başka bir ifadeyle, tavsiye sonrası hisse senetleri ile ilgili yeni bir fiyat seviyesi oluşmuş ve bu seviye kısa vadede korunmuştur. $\mathrm{Bu}$ durum, yatırımcıların uzman tavsiyelerini önemli ölçüde dikkate aldığını ve yatırım kararlarını bu tavsiyeleri dikkate alarak verdiğini göstermektedir. Tavsiye öncesi fiyat hareketliliği incelendiğinde ise özellikle duyuru öncesi ilk gün önerilen hisse senedi fiyatlarının yükselmeye başladığı görülmektedir. Bu sonuç, önerilen hisse senetleri ile ilgili yatırımcıların duyuru öncesinde bir beklentilerinin olduğunu ve bazı yatırımcıların bu doğrultuda pozisyon aldığına işaret 
etmektedir. Diğer bir muhtemel açıklama ise, hisse senedi fiyatlarının duyuru öncesinde bir artış trendi içerisinde oldukları ve uzman tavsiyelerinin bu trendi dikkate alarak yatırımcılara "al" tavsiyesi verdikleridir.

Ayrıca Tablo 1'in alt bölümünde yer alan $[-5,-1],[-1,+1],[-5,+5]$ ve $[-15,+15]$ olay aralıkları için hesaplanan ortalama kümülatif anormal getiriler istatistiksel olarak $\% 1$ ve $\% 5$ seviyesinde anlamlı bulunmuştur. Sonuç itibariyle, tavsiyelerin duyurulduğu olay gününü takip eden günlerde hisse senetlerinde aşırı getiri söz konusudur. Hisse senetlerinde açıklama öncesi ve sonrası aşırı getirilerin varlığı piyasanın etkin olmadığını göstermektedir ve dolayısıyla $\mathrm{H}_{1}$ hipotezi kabul edilmiştir. Yani yatırımcılar aracı kurum tavsiyelerine pozitif tepki vermektedirler. $[-15,+15]$ aralığında elde edilen ortalama kümülatif anormal getiriler Şekil 1'de sunulmuştur. Şekil 1'den de görülebileceği gibi duyuru öncesi başlayan fiyat hareketliliği duyurudan sonraki günlerde de devam etmektedir. Duyurudan 15 gün öncesi ve 15 gün sonrası dikkate alınarak hesaplanan kümülatif anormal getiriler incelendiğinde kümülatif anormal getirilerin $\% 5$ 'in üzerinde olduğu görülmektedir.

Tablo 1. Önerilen Hisse Senetleri Listesine Dahil Edilen Hisse Senetlerinin Anormal

Getirisi

\begin{tabular}{lllllll}
\hline Gün & $\mathrm{AG}(\%)$ & $\mathrm{t}(\mathrm{OAG})$ & $\mathrm{OKAG}(\%)$ & $\mathrm{t}(\mathrm{OKAG})$ & $\% \mathrm{AG} \geq 0$ & z-değeri \\
\hline-15 & 0,009 & $(0,042)$ & 0,009 & $(0,042)$ & 48,82 & $(-0,27)$ \\
-14 & 0,030 & $(0,148)$ & 0,039 & $(0,120)$ & 47,24 & $(-0,62)$ \\
-13 & 0,030 & $(0,137)$ & 0,069 & $(0,186)$ & 48,03 & $(-0,44)$ \\
-12 & $-0,087$ & $(-0,464)$ & $-0,018$ & $(-0,043)$ & 43,31 & $(-1,51)$ \\
-11 & 0,358 & $(1,862)$ & 0,341 & $(0,703)$ & 56,69 & $(1,51)$ \\
-10 & 0,177 & $(0,958)$ & 0,518 & $(0,985)$ & 59,84 & $(1,54)$ \\
-9 & 0,112 & $(0,722)$ & 0,629 & $(1,134)$ & 48,03 & $(-0,44)$ \\
-8 & 0,241 & $(1,254)$ & 0,871 & $(1,459)$ & 53,54 & $(0,80)$ \\
-7 & $-0,142$ & $(-0,773)$ & 0,729 & $(1,210)$ & 43,31 & $(-1,51)$ \\
-6 & $-0,173$ & $(-1,095)$ & 0,556 & $(0,870)$ & 46,46 & $(-0,80)$ \\
-5 & $-0,198$ & $(-1,160)$ & 0,358 & $(0,551)$ & 40,94 & $(-2,04)$ \\
-4 & 0,445 & $(2,233)^{*}$ & 0,803 & $(1,129)$ & 55,12 & $(1,15)$ \\
-3 & $-0,062$ & $(-0,305)$ & 0,741 & $(1,015)$ & 50,39 & $(0,09)$ \\
-2 & 0,311 & $(1,477)$ & 1,052 & $(1,500)$ & 55,91 & $(1,33)$ \\
-1 & 0,564 & $(2,607)^{* *}$ & 1,616 & $(2,308)^{*}$ & 59,84 & $(2,22)^{*}$ \\
\hline 0 & 1,448 & $(5,562)^{* *}$ & 1,448 & $(5,562)^{* *}$ & 71,65 & $(4,88)^{* *}$ \\
\hline 1 & 0,779 & $(3,605)^{* *}$ & 2,226 & $(6,361)^{* *}$ & 59,84 & $(2,22)^{*}$ \\
2 & 0,649 & $(2,822)^{* *}$ & 2,875 & $(6,775)^{* *}$ & 58,27 & $(1,86)^{*}$ \\
3 & 0,052 & $(0,309)$ & 2,927 & $(6,554)^{* *}$ & 44,09 & $(-1,33)$ \\
4 & 0,115 & $(0,674)$ & 3,041 & $(6,589)^{* *}$ & 48,03 & $(-0,44)$ \\
5 & 0,185 & $(1,082)$ & 3,226 & $(6,533)^{* *}$ & 50,39 & $(0,09)$ \\
6 & 0,008 & $(0,045)$ & 3,234 & $(6,169)^{* *}$ & 45,67 & $(-0,98)$ \\
7 & 0,170 & $(0,840)$ & 3,404 & $(6,321)^{* *}$ & 54,33 & $(0,98)$ \\
8 & $-0,16$ & $(-0,100)$ & 3,388 & $(6,042)^{* *}$ & 49,61 & $(-0,09)$ \\
9 & $-0,223$ & $(-1,143)$ & 3,165 & $(5,465)^{* *}$ & 46,46 & $(-0,80)$ \\
10 & 0,284 & $(1,378)$ & 3,449 & $(5,241)^{* *}$ & 54,33 & $(0,98)$ \\
& & & & & &
\end{tabular}




\begin{tabular}{lllllll}
11 & 0,060 & $(0,317)$ & 3,509 & $(5,350)^{* *}$ & 51,97 & $(0,44)$ \\
12 & 0,012 & $(0,070)$ & 3,521 & $(5,041)^{* *}$ & 46,46 & $(-0,80)$ \\
13 & 0,067 & $(0,363)$ & 3,558 & $(5,071)^{* *}$ & 46,46 & $(-0,80)$ \\
14 & $-0,001$ & $(-0,004)$ & 3,587 & $(4,917)^{* *}$ & 51,18 & $(0,27)$ \\
15 & 0,114 & $(0,557)$ & 3,701 & $(5,021)^{* *}$ & 44,88 & $(-1.15)$ \\
\hline
\end{tabular}

Olay Penceresi (\%)

$[-5,-1] \quad 1,060 \quad *$

$[-1,+1] \quad 2,791 \quad * *$

$[-5,+5] \quad 4,286 \quad * *$

$[-15,+15] \quad 5,317 \quad * *$

Notlar: OAG, OKAG ve AG sirasiyla ortalama anormal getiri, ortalama kümülatif anormal getiri ve anormal getiriyi ifade etmektedir. "Gün" sütununda yer alan " 0 " ifadesi önerinin yapıldığı günü göstermektedir. \%AG örneklemdeki sıfirdan büyük gözlem sayısının toplam gözlem sayısına oranını ifade etmektedir. $\mathrm{Z}$ değerleri \%AG değerlerinin $0,5^{5}$ ten büyük olma olasılığını test eden değerlerdir. ** ve * sırasıyla $\% 1$ ve $\% 5$ anlamlılık düzeylerini ifade etmektedir. Tablonun alt kısmında farklı olay pencerelerindeki ortalama kümülatif anormal getiriler raporlanmıştır. Örneklem büyüklüğü 127'dir.

Şekil 1. Önerilen Hisse Senetleri Listesine Dahil Edilen Hisse Senetlerinin Kümülatif Anormal Getirileri $[-15,+15]$

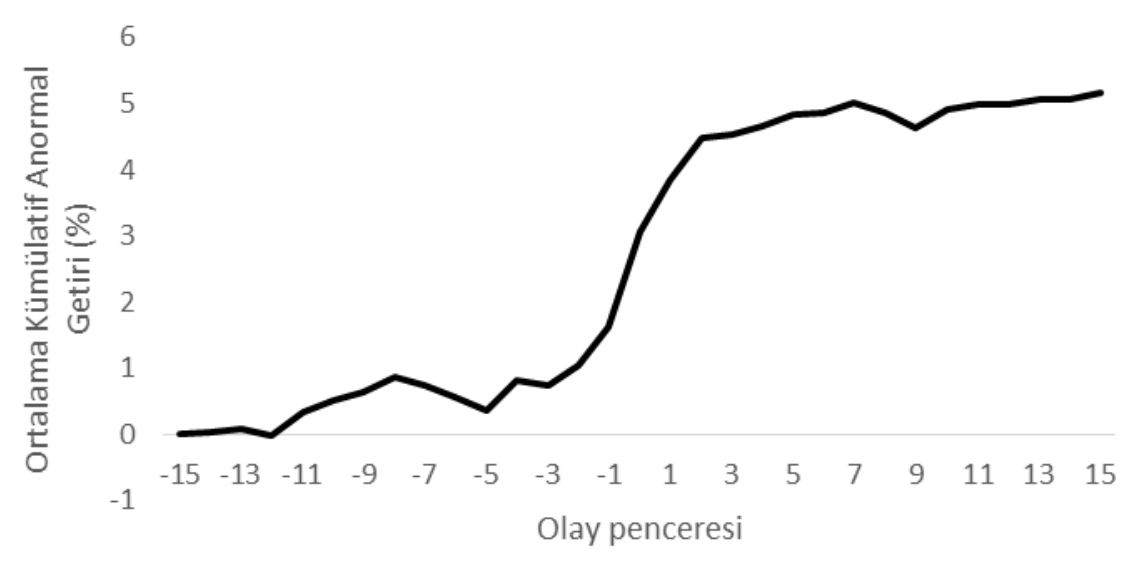

Diğer yandan, olay günü normalüstü getiri elde eden hisse senedi sayısının toplam hisse senedi oranı yaklaşı $\% 72$ seviyesindedir. Bu oran duyurudan sonraki iki gün de yaklaşık \%58-60 seviyesindedir. Bu sonuç, kümülatif anormal getirilerden elde edilen sonuçları doğrulamaktadır. Analize dahil edilen hisse senetlerinin önemli bir bölümü duyuru sonrası normalüstü getiri elde etmişlerdir² ${ }^{2}$.

Tablo 2'de önerilen hisse senetleri listesinden çıkarılan hisse senetlerinin anormal ve kümülatif anormal getirileri sunulmaktadır. Tablo incelendiğinde özellikle olay günü listeden çıkartılan hisse senetlerinde anlamlı bir düşüş gözlenmiştir $(\% 0,65)$. Olay sonrası 10 günlük süre incelendiğinde ise 10 günün 9'unda listeden çıkartılan hisse senedi fiyatlarında anormal düşüş gözlenmektedir. 10. günden sonra ise hisse senedi

\footnotetext{
${ }^{2}$ Çalışmada işlem maliyetleri göz ardı edilmiştir.
} 
fiyatlarında bir miktar toparlanma görülse de, bu durum önceki kayıpları azaltacak seviyede değildir. $\mathrm{Bu}$ sonuç, piyasanın uzman tavsiyelerinin yatırımcılar tarafından dikkate alındığına ve yatırımcıların bu hisse senetlerini portföylerinden çıkarma eğiliminde olduklarına işaret etmektedir. Kümülatif anormal getiriler incelendiğinde ise 0-15 gün aralığında listeden çıkartılan hisse senetlerinin fiyatlarında yaklaşık \%1,6 düşüş yaşandığı görülmektedir. Olay günü sonrası elde edilen negatif kümülatif anormal getirilerin tamamı istatistiksel olarak anlamlıdır. Ek olarak, olay günü ve olaydan bir sonraki gün öneri listesinden çıkartılan hisse senetlerinin yaklaşık \%65-66'lık bölümü hisse senedi fiyatlarında düşüş yaşamıştır. Bu sonuç da listeden çıkarılma duyurusunun yatırımcılar tarafından olumsuz bir haber olarak görüldüğ̈ ve yatırımcıların bu hisse senetlerini portföylerinden çıkarma eğiliminde olduklarını göstermektedir. Sonuç olarak, listeden çıkartılan hisse senedi fiyatlarında duyuru sonrası anormal düşüş yaşanacağ 1 şeklinde oluşturulan $\mathrm{H}_{2}$ kabul edilmiştir. Tabloda dikkat çeken diğer bir nokta ise duyuru öncesi hisse senedi getirilerinin genel olarak pozitif olmasıdır. Duyuru öncesini kapsayan 15 günlük olay penceresinin 11 gününde hisse senedi fiyatları artmıştır. İş yatırım raporları incelendiğinde hisse senetlerinin öneri listesinden çıkartılmasının en büyük nedenlerinden biri olarak hisse senetlerinin kendilerinden beklenen potansiyele ulaşması ve gelecekte bu hisse senetlerinden geçmişe oranla olumlu performansın beklenmemesi olarak belirtilmiştir. Tablo 2'nin alt bölümünde raporlanan farklı olay pencereleri dikkate alınarak elde edilen kümülatif anormal getirilerin istatistiksel olarak anlamsız olmasının en önemli nedeni budur. Başka bir ifadeyle, duyuru sonrası hisse senedi fiyatlarında görülen anormal düşüş, duyurudan önce gerçekleşen fiyat artışı neticesinde etkisini kaybetmiştir.

Şekil 2'de öneri listesinden çıkartılan hisse senetlerinin $-15,+15$ olay penceresi içerisindeki ortalama kümülatif anormal getirileri görülmektedir. Şekilde dikkate çeken en önemli nokta fiyatlarda duyuru öncesi yaşanan yükselişin aksine duyuru günü ve sonrasında yaşanan büyük düşüştür. Duyurudan sonraki hafta hisse senedi fiyatlarında bir miktar toparlanma yaşansa da hisse senedi fiyatlarının duyuru öncesi seviyelerine ulaştı̆̆ını söylemek mümkün değildir.

Tablo 3'te önerilmeyen hisse senetleri listesine dahil edilen hisse senetleri ile ilgili olay çalışmasının sonuçları verilmiştir. Buna göre duyurunun yapıldığı gün \% 1,38 lik negatif anormal getiri görülmüştür ve bu değer \%1 düzeyinde anlamlıdır. 
Şekil 2. Önerilen Hisse Senetleri Listesinden Çıkarılan Hisse Senetlerinin Kümülatif Anormal Getirileri [-15,+15]

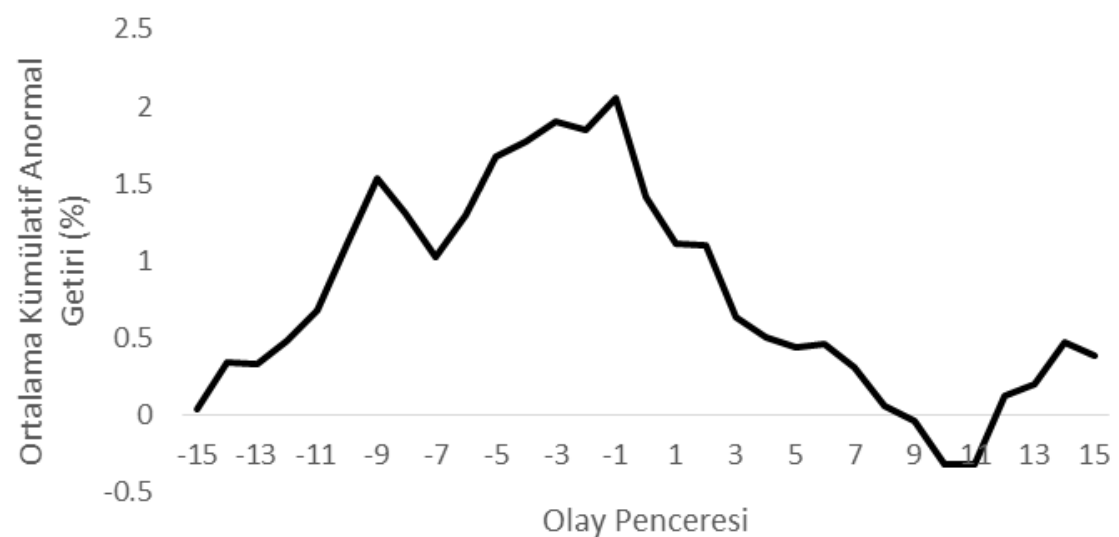

Tablo 2. Önerilen Hisse Senetleri Listesinden Çıkarılan Hisse Senetlerinin Anormal

Getirisi

\begin{tabular}{lllllll}
\hline Gün & OAG $(\%)$ & $\mathrm{t}(\mathrm{OAG})$ & $\mathrm{OKAG}(\%)$ & $\mathrm{t}(\mathrm{OKAG})$ & $\% \mathrm{AG} \leq 0$ & $\mathrm{z}$-değeri \\
\hline-15 & 0,041 & $(0,241)$ & 0,041 & $(0,241)$ & 50,86 & $(0,19)$ \\
-14 & 0,306 & $(1,713)$ & 0,347 & $(1,428)$ & 44,83 & $(-1,11)$ \\
-13 & $-0,020$ & $(-0,109)$ & 0,327 & $(1,130)$ & 50,86 & $(0,19)$ \\
-12 & 0,157 & $(0,865)$ & 0,484 & $(1,431)$ & 48,28 & $(-0,37)$ \\
-11 & 0,193 & $(1,034)$ & 0,677 & $(1,749)$ & 47,41 & $(-0,56)$ \\
-10 & 0,439 & $(2,004)^{*}$ & 1,116 & $(2,418)^{*}$ & 44,83 & $(-1,11)$ \\
-9 & 0,419 & $(1,921)$ & 1,535 & $(2,905)^{* *}$ & 41,38 & $(-1,86)$ \\
-8 & $-0,232$ & $(-1,460)$ & 1,303 & $(2,336)^{*}$ & 56,03 & $(1,30)$ \\
-7 & $-0,283$ & $(-1,284)$ & 1,020 & $(1,671)$ & 50,00 & $(0,00)$ \\
-6 & 0,277 & $(1,302)$ & 1,297 & $(1,968)$ & 52,59 & $(0,56)$ \\
-5 & 0,375 & $(1,529)$ & 1,672 & $(2,138)^{*}$ & 48,28 & $(-0,37)$ \\
-4 & 0,106 & $(0,503)$ & 1,778 & $(2,023)^{*}$ & 50,86 & $(0,19)$ \\
-3 & 0,129 & $(0,575)$ & 1,907 & $(2,112)^{*}$ & 53,45 & $(0,74)$ \\
-2 & $-0,062$ & $(-0,263)$ & 1,846 & $(1,877)$ & 50,00 & $(0,00)$ \\
-1 & 0,212 & $(0,817)$ & 2,058 & $(1,942)$ & 56,03 & $(1,30)$ \\
\hline 0 & $-0,647$ & $(-2,670)^{* *}$ & $-0,647$ & $(-2,670)^{* *}$ & 66,38 & $(3,53)^{* *}$ \\
\hline 1 & $-0,302$ & $(-1,467)$ & $-0,949$ & $(-3,122)^{* *}$ & 64,66 & $(3,16)^{* *}$ \\
2 & $-0,010$ & $(-0,054)$ & $-0,959$ & $(-2,665)^{* *}$ & 47,41 & $(-0,56)$ \\
3 & $-0,468$ & $(-2,265)^{*}$ & $-1,428$ & $(-3,640)^{* *}$ & 57,76 & $(1,67)^{*}$ \\
4 & $-0,123$ & $(-0,572)$ & $-1,550$ & $(-3,992)^{* *}$ & 50,86 & $(0,19)$ \\
5 & $-0,067$ & $(-0,292)$ & $-1,617$ & $(-3,627)^{* *}$ & 50,00 & $(0,00)$ \\
6 & 0,025 & $(0,111)$ & $-1,592$ & $(-3,411)^{* *}$ & 54,31 & $(0,93)$ \\
7 & $-0,153$ & $(-0,789)$ & $-1,745$ & $(-3,338)^{* *}$ & 56,03 & $(1,30)$ \\
8 & $-0,252$ & $(-1,255)$ & $-1,997$ & $(-3,536)^{* *}$ & 54,31 & $(0,93)$ \\
9 & $-0,096$ & $(-0,503)$ & $-2,093$ & $(-3,621)^{* *}$ & 49,14 & $(-0,19)$ \\
10 & $-0,286$ & $(-1,282)$ & $-2,379$ & $(-3,859)^{* *}$ & 50,86 & $(0,19)$ \\
11 & 0,001 & $(0,003)$ & $-2,379$ & $(-3,638)^{* *}$ & 49,14 & $(-0,19)$ \\
12 & 0,442 & $(2,082)^{*}$ & $-1,937$ & $(-2,978)^{* *}$ & 42,24 & $(-1,67)$ \\
13 & 0,075 & $(0,431)$ & $-1,861$ & $(-2,992)^{* *}$ & 54,31 & $(0,93)$ \\
& & & & & &
\end{tabular}




$\begin{array}{lllllll}14 & 0,271 & (1,312) & -1,590 & (-2,420)^{*} & 48,28 & (-0,37) \\ 15 & -0,087 & (-0,415) & -1,677 & (-2,424)^{*} & 55,17 & (1,11)\end{array}$

Olay Penceresi (\%)

$[-5,-1] \quad 0,760$

$[-1,+1] \quad-0,737$

$[-5,+5] \quad-0,857$

$[-15,+15] \quad 0,381$

Notlar: OAG, OKAG ve AG sirasıyla ortalama anormal getiri, ortalama kümülatif anormal getiri ve anormal getiriyi ifade etmektedir. "Gün" sütununda yer alan " 0 " ifadesi önerinin yapıldığı günü göstermektedir. \%AG örneklemdeki sıfırdan küçük gözlem sayısının toplam gözlem sayısına oranını ifade etmektedir. $Z$ değerleri \%AG değerlerinin 0,5 'ten küçük olma olasılığını test eden değerlerdir. ** ve * sırasıyla $\% 1$ ve $\% 5$ anlamlılı düzeylerini ifade etmektedir. Tablonun alt kısmında farklı olay pencerelerindeki ortalama kümülatif anormal getiriler raporlanmıştır. Örneklem büyüklüğü 116'dır.

Tablo 3. Önerilmeyen Hisse Senedi Listesine Dahil Edilen Hisse Senetlerinin Anormal Getirisi

\begin{tabular}{lllllll}
\hline Gün & OAG $(\%)$ & $\mathrm{t}(\mathrm{OAG})$ & $\mathrm{OKAG}(\%)$ & $\mathrm{t}(\mathrm{OKAG})$ & $\% \mathrm{AG} \leq 0$ & $\mathrm{z}$-değeri \\
\hline-15 & 0,487 & $(1,439)$ & 0,487 & 1,439 & 43,33 & $(-0,73)$ \\
-14 & 1,297 & $(3,199)^{* *}$ & 1,785 & $3,737^{* *}$ & 33,33 & $(-1,82)$ \\
-13 & 0,102 & $(0,180)$ & 1,887 & $2,201^{*}$ & 46,67 & $(-0,36)$ \\
-12 & 0,426 & $(1,444)$ & 2,313 & $2,379^{* *}$ & 50,00 & $(0,00)$ \\
-11 & $-0,585$ & $(-1,335)$ & 1,727 & $2,311^{*}$ & 70,00 & $(2,19)^{* *}$ \\
-10 & $-0,023$ & $(-0,061)$ & 1,704 & $2,553^{*}$ & 36,67 & $(-1,46)$ \\
-9 & 0,299 & $(1,111)$ & 2,003 & $2,737^{* *}$ & 43,33 & $(-0,73)$ \\
-8 & 0,131 & $(0,597)$ & 2,133 & $2,702^{*}$ & 46,67 & $(-0,36)$ \\
-7 & $-0,090$ & $(-0,433)$ & 2,044 & $2,642^{*}$ & 60,00 & $(1,09)$ \\
-6 & 0,462 & $(1,535)$ & 2,505 & $2,958^{* *}$ & 40,00 & $(-1,09)$ \\
-5 & 0,575 & $(1,823)$ & 3,080 & $3,289^{* *}$ & 43,33 & $(-0,73)$ \\
-4 & 0,329 & $(1,116)$ & 3,409 & $3,386^{* *}$ & 36,67 & $(-1,46)$ \\
-3 & $-0,317$ & $(-0,954)$ & 3,093 & $3,097^{* *}$ & 50,00 & $(0,00)$ \\
-2 & 0,555 & $(1,252)$ & 3,648 & $3,320^{* *}$ & 43,33 & $(-0,73)$ \\
-1 & $-0,222$ & $(-0,412)$ & 3,426 & $3,105^{* *}$ & 56,67 & $(0,73)$ \\
\hline 0 & $-1,378$ & $(-3,123)^{* *}$ & $-1,378$ & $-3,123^{* *}$ & 73,33 & $(2,55)^{* *}$ \\
\hline 1 & $-0,330$ & $(-0,782)$ & $-1,708$ & $-2,707^{*}$ & 60,00 & $(1,09)$ \\
2 & 0,003 & $(0,011)$ & $-1,705$ & $-2,778^{* *}$ & 53,33 & $(0,36)$ \\
3 & $-0,365$ & $(-1,122)$ & $-2,070$ & $-3,434^{* *}$ & 50,00 & $(0,00)$ \\
4 & $-0,091$ & $(-0,351)$ & $-2,161$ & $-3,226^{* *}$ & 46,67 & $(-0,36)$ \\
5 & $-0,467$ & $(-1,856)$ & $-2,628$ & $-3,339^{* *}$ & 70,00 & $(2,19)^{* *}$ \\
6 & $-0,253$ & $(-0,948)$ & $-2,880$ & $-3,322^{* *}$ & 56,67 & $(0,73)$ \\
7 & $-0,315$ & $(-1,462)$ & $-3,196$ & $-3,647^{* *}$ & 63,33 & $(1,46)$ \\
8 & 0,051 & $(0,207)$ & $-3,144$ & $-3,951^{* *}$ & 53,33 & $(0,36)$ \\
9 & $-0,197$ & $(-0,789)$ & $-3,341$ & $-4,329^{* *}$ & 66,67 & $(1,82)^{*}$ \\
10 & 0,062 & $(0,170)$ & $-3,279$ & $-3,620^{* *}$ & 50,00 & $(0,00)$ \\
11 & $-0,364$ & $(-1,427)$ & $-3,643$ & $-3,876^{* *}$ & 63,33 & $(1,46)$ \\
12 & $-0,375$ & $(-1,089)$ & $-4,018$ & $-4,006^{* *}$ & 56,67 & $(0,73)$ \\
13 & $-0,018$ & $(-0,075)$ & $-4,036$ & $-3,876^{* *}$ & 53,33 & $(0,36)$ \\
& & & & & &
\end{tabular}




\begin{tabular}{lllllll}
14 & $-0,421$ & $(-1,379)$ & $-4,457$ & $-3,994 * *$ & 53,33 & $(0,36)$ \\
15 & 0,240 & $(0,693)$ & $-4,217$ & $-3,203 * *$ & 53,33 & $(0,36)$ \\
\hline
\end{tabular}

Olay Penceresi (\%)

[-5,-1] 0,921

$[-1,+1] \quad-1,930$

$[-5,+5] \quad-1,707$

$[-15,+15] \quad-0,791$

Notlar: OAG, OKAG ve AG sirasılya ortalama anormal getiri, ortalama kümülatif anormal getiri ve anormal getiriyi ifade etmektedir. "Gün" sütununda yer alan "0" ifadesi önerinin yapıldığı günü göstermektedir. \%AG örneklemdeki sıfırdan küçük gözlem sayısının toplam gözlem sayısına oranını ifade etmektedir. $\mathrm{Z}$ değerleri \%AG değerlerinin $0,5^{\prime}$ ten küçük olma olasılığını test eden değerlerdir. ** ve * sırasıyla $\% 1$ ve $\% 5$ anlamlılık düzeylerini ifade etmektedir. Tablonun alt kısmında farklı olay pencerelerindeki ortalama kümülatif anormal getiriler raporlanmıştır. Örneklem büyüklüğü 30'dur.

Şekil 3. Önerilmeyen Hisse Senetleri Listesine Dahil Edilen Hisse Senetlerinin Kümülatif Anormal Getirileri [-15,+15]

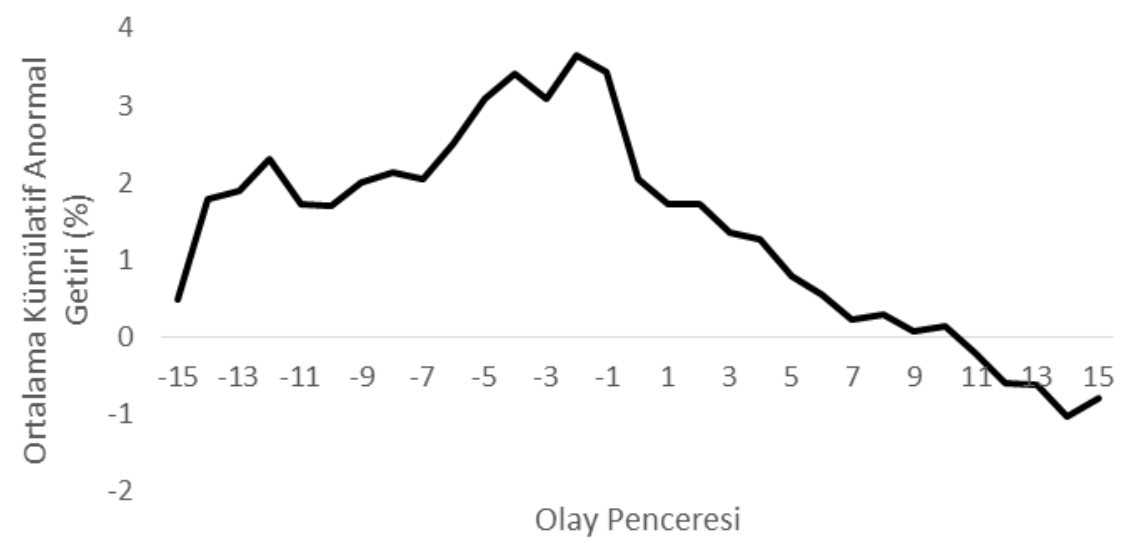

Duyuru sonrası kümülatif anormal getiriler incelendiğinde ise, Tablo 2'deki duruma benzer bir durumla karşı kaşıya olduğumuz görülmektedir. Duyuru öncesi ortaya çıkan olumlu fiyat hareketleri, duyuru sonrası fiyatlarda düşüş şeklinde kendini göstermiştir. Duyuru öncesi getiriler incelendiğinde, hisse senetlerinin pozitif anormal getiri elde ettiği görülmektedir. Bunun en önemli nedeni, aracı kurumun kendisinden beklenen potansiyele ulaşan bazı şirketleri gelecekte artık daha fazla getiri yaratmayacağı düşünülerek önerilmeyen hisse senetleri listesine eklemesidir. Başka bir ifadeyle, önerilmeyen listesine eklenen bazı şirketlerin bu listeye eklenme nedeni aracı kurum tarafından potansiyellerine ulaştıklarının düşünülmesidir. Bu durum da, duyuru öncesi pozitif fiyat değişimi olarak tablolara yansımaktadır. Tabloda dikkat çeken önemli bir nokta da duyuru sonrası fiyatlardaki düşüşün istikrarlı olarak devam etmesidir. $\mathrm{Bu}$ sonuç, olay günü görülen fiyat düşüşlerinin fiyat baskısından çok duyurunun bilgi içeriği ile ilgili olduğu görüşünü desteklemektedir. Başka bir ifadeyle, yatırımcilar önerilmeyen hisse senetleri listesine eklenen firmaların gelecekte olumsuz performans göstereceğine inanmakta ve bu hisse senetlerini portföylerinden kalıcı 
olarak çıkarmaktadırlar. Şekil 3 ile Şekil 2 karşılaştırıldığında ise, önerilmeyen hisse senedi listesine eklenen şirketlerin duyurudan daha fazla etkilendiği göze çarpmaktadır. Diğer bir deyişle, piyasaya yeni gelen olumsuz bir gelişme (önerilmeyen listesine dahil olma), daha önce ortaya çıkmış olumlu bir gelişmenin ortadan kalkmasına (önerilen listesinden çıkarılma) göre hisse senedi fiyatları üzerinde daha fazla etkiye sahiptir. Bu durum, davranışsal finans literatüründe sıklıkla yer alan, yatırımcıların olumsuz haberlere daha fazla tepki vermesi şeklinde açıklanabilir. Duyuru sonrası 15 günlük sürede oluşan fiyatlardaki yaklaşık \%4'lük düşüş (Tablo 3) bu görüşü destekler durumdadır. 31 günlük olay penceresi kapsamında oluşan kümülatif anormal getirilerin sunulduğu Şekil 3'te de duyuru sonrası fiyatlardaki düşüş açık bir şekilde görülmektedir. Sonuç olarak $\mathrm{H}_{3}$ doğrulanmıştır.

Tablo 4 'te önerilmeyen hisse senetleri listesinden çıkartılan hisse senetleri ile ilgili sonuçlar verilmiştir. Tablodan görülebileceği gibi, her ne kadar olay günü piyasanın duyuruya pozitif tepki verdiği görülse de bu tepki istatistiksel olarak anlamlı değildir. Olaydan sonraki günler incelendiğinde ise ne ortalama anormal getiriler ne de kümülatif anormal getiriler istatistiksel olarak anlamlıdır. Olay günü pozitif anormal getiri gerçekleşen hisse senedi sayısının örneklemdeki toplam hisse senedi sayısına oranı yaklaşık olarak 0,54 'tür ve z değeri anlamsızdır. $\mathrm{Bu}$ da, önerilmeyen hisse senedi listesinden çıkartılma duyurusunun piyasa üzerinde herhangi bir olumlu etki yaratmadığını göstermektedir. $\mathrm{Bu}$ nedenle $\mathrm{H}_{4}$ hipotezi reddedilmiştir. Şekil 4'te olay gününden 15 gün öncesi ve 15 gün sonrasını içeren kümülatif anormal getiriler gösterilmektedir. Grafikten de görülebileceği gibi duyuru sonrası süreçte hisse senedi dalgalı bir seyir izlemiştir. Her ne kadar duyuru sonrası ilk iki gün hisse senedi fiyatlarında bir miktar artış gözlense de, piyasanın duyuruya olumlu tepki verdiğini doğrulayacak herhangi bir bulguya rastlanmamıştır.

Elde edilen sonuçlar genel olarak değerlendirildiğinde, yatırımcıların yatırım önerilerini dikkate aldıkları görülmektedir. Sadece önerilmeyen hisse senetleri listesinden çıkartılan hisse senetlerinin fiyatlarında anlamlı bir hareketlilik gözlenmemektedir. 
Şekil 4: Önerilmeyen Hisse Senetleri Listesinden Çıkarılan Hisse Senetlerinin Anormal Getirisi $[-15,+15]$

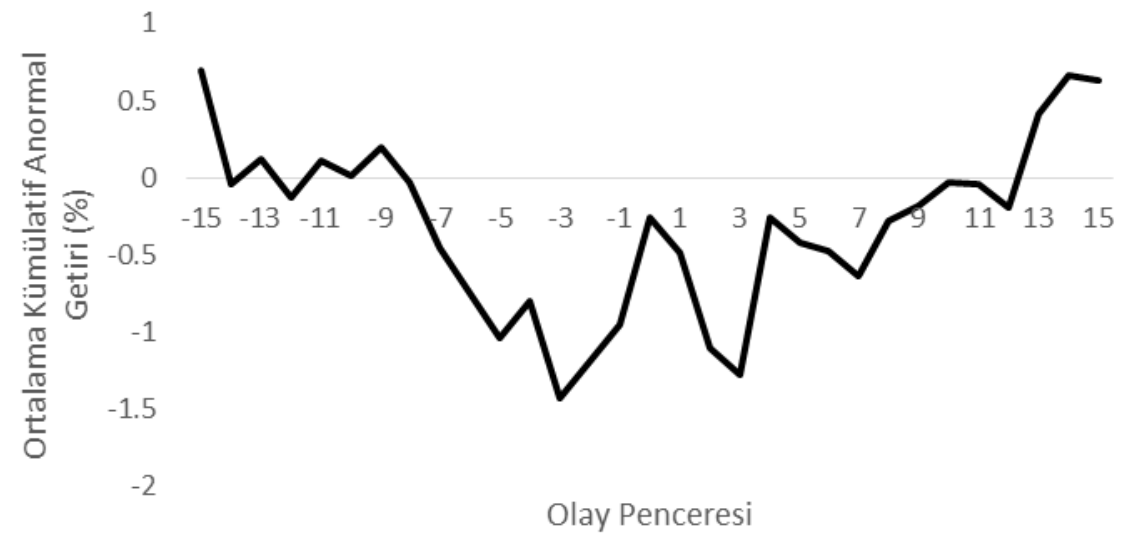

Tablo 4: Önerilmeyen Hisse Senetleri Listesinden Çıkarılan Hisse Senetlerinin Anormal Getirisi

\begin{tabular}{|c|c|c|c|c|c|c|}
\hline Gün & $\mathrm{OAG}(\%)$ & $\mathrm{t}(\mathrm{OAG})$ & OKAG $(\%)$ & $\mathrm{t}(\mathrm{OKAG})$ & $\% A G \geq 0$ & z-değeri \\
\hline-15 & 0,699 & $(2,433)^{*}$ & 0,699 & $(2,433)^{*}$ & 69,23 & $(1,96)^{*}$ \\
\hline-14 & $-0,742$ & $(-1,806)$ & $-0,044$ & $(-0,087)$ & 46,15 & $(-0,39)$ \\
\hline-13 & 0,162 & $(0,563)$ & 0,118 & $(0,193)$ & 61,54 & $(1,18)$ \\
\hline-12 & $-0,245$ & $(-0,736)$ & $-0,126$ & $(-0,196)$ & 50,00 & $(0,00)$ \\
\hline-11 & 0,233 & $(0,484)$ & 0,107 & $(0,130)$ & 50,00 & $(0,00)$ \\
\hline-10 & $-0,092$ & $(-0,195)$ & 0,015 & $(0,014)$ & 50,00 & $(0,00)$ \\
\hline-9 & 0,184 & $(0,946)$ & 0,199 & $(0,198)$ & 50,00 & $(0,00)$ \\
\hline-8 & $-0,226$ & $(-0,467)$ & $-0,027$ & $(-0,025)$ & 61,54 & $(1,18)$ \\
\hline-7 & $-0,426$ & $(-0,654)$ & $-0,453$ & $(-0,352)$ & 53,85 & $(0,39)$ \\
\hline-6 & $-0,292$ & $(-0,779)$ & $-0,745$ & $(-0,559)$ & 50,00 & $(0,00)$ \\
\hline-5 & $-0,291$ & $(-0,706)$ & $-1,036$ & $(-0,909)$ & 34,62 & $(-1,57)$ \\
\hline-4 & 0,232 & $(0,591)$ & $-0,804$ & $(-0,686)$ & 50,00 & $(0,00)$ \\
\hline-3 & $-0,624$ & $(-1,164)$ & $-1,428$ & $(-1,082)$ & 46,15 & $(-0,39)$ \\
\hline-2 & 0,238 & $(0,520)$ & $-1,190$ & $(-0,902)$ & 57,69 & $(0,78)$ \\
\hline-1 & 0,241 & $(0,715)$ & $-0,948$ & $(-0,680)$ & 53,85 & $(0,39)$ \\
\hline 0 & 0,686 & $(1,643)$ & 0,686 & $(1,643)$ & 53,85 & $(0,39)$ \\
\hline 1 & $-0,221$ & $(-0,628)$ & 0,465 & $(0,865)$ & 57,69 & $(0,78)$ \\
\hline 2 & $-0,620$ & $(-1,830)$ & $-0,155$ & $(-0,257)$ & 46,15 & $(-0,39)$ \\
\hline 3 & $-0,168$ & $(-0,470)$ & $-0,322$ & $(-0,498)$ & 38,46 & $(-1,18)$ \\
\hline 4 & 1,018 & $(2,588)^{*}$ & 0,696 & $(0,950)$ & 50,00 & $(0,00)$ \\
\hline 5 & $-0,172$ & $(-0,566)$ & 0,523 & $(0,629)$ & 53,85 & $(0,39)$ \\
\hline 6 & $-0,052$ & $(-0,139)$ & 0,471 & $(0,543)$ & 53,85 & $(0,39)$ \\
\hline 7 & $-0,165$ & $(-0,471)$ & 0,306 & $(0,360)$ & 46,15 & $(-0,39)$ \\
\hline 8 & 0,365 & $(1,443)$ & 0,671 & $(0,721)$ & 53,85 & $(0,39)$ \\
\hline 9 & 0,097 & $(0,283)$ & 0,768 & $(0,769)$ & 57,69 & $(0,78)$ \\
\hline 10 & 0,146 & $(0,421)$ & 0,914 & $(0,940)$ & 61,54 & $(1,18)$ \\
\hline 11 & $-0,008$ & $(-0,024)$ & 0,906 & $(0,973)$ & 61,54 & $(1,18)$ \\
\hline 12 & $-0,152$ & $(-0,456)$ & 0,754 & $(0,777)$ & 53,85 & $(0,39)$ \\
\hline 13 & 0,606 & $(1,634)$ & 1,360 & $(1,321)$ & 61,54 & $(1,18)$ \\
\hline
\end{tabular}




\begin{tabular}{|c|c|c|c|c|c|c|}
\hline 14 & 0,257 & $(0,586)$ & 1,617 & $(1,303)$ & 57,69 & $(0,78)$ \\
\hline 15 & $-0,040$ & $(-0,136)$ & 1,577 & $(1,295)$ & 65,38 & $(1,57)$ \\
\hline \multicolumn{7}{|c|}{ Olay Penceresi (\%) } \\
\hline$[-5,-1]$ & $-0,203$ & & & & & \\
\hline$[-1,+1]$ & 0,706 & & & & & \\
\hline$[-5,+5]$ & 0,320 & & & & & \\
\hline$[-15,+15]$ & 0,628 & & & & & \\
\hline
\end{tabular}

Notlar: OAG, OKAG ve AG sirasıyla ortalama anormal getiri, ortalama kümülatif anormal getiri ve anormal getiriyi ifade etmektedir. "Gün" sütununda yer alan " 0 " ifadesi önerinin yapıldığı günü göstermektedir. \%AG örneklemdeki sıfırdan büyük gözlem sayısının toplam gözlem sayısına oranını ifade etmektedir. Z değerleri \%AG değerlerinin 0,5 'ten büyük olma olasıllğını test eden değerlerdir. ** ve * sırasıyla $\% 1$ ve $\% 5$ anlamlılık düzeylerini ifade etmektedir. Tablonun alt kısmında farklı olay pencerelerindeki ortalama kümülatif anormal getiriler raporlanmıştır. Örneklem büyüklüğü 26'dur.

\section{SONUÇ}

Etkin Piyasalar Hipotezi'ne göre hisse senedi fiyatları yeni gelen haberlere hızlı bir şekilde tepki vermeli ve kimse piyasadan normalin üstünde getiri elde edememelidir. $\mathrm{Bu}$ teori genel olarak menkul kıymet fiyatlarının pazara ulaşan tüm bilgileri yansıttığını ortaya koymaktadır. Hipoteze göre hisse senedi fiyatı, herkes tarafindan ulaşılabilen bilgiyi yansıtmaktadır. Pazar etkinliği Fama tarafından ortaya konulduğu gibi, zayıf, yarı güçlü ve güçlü olabilecektir.

Uzun y1llardır borsa, gazete veya dergilerde yayımlanan uzman tavsiyelerinin hisse senedi fiyatına etkisinin olup olmadığı ve bu tavsiyelerin kullanılarak anormal getirinin elde edilip edilemediği tartışma konusu olmuştur. Sonuç olarak bu konuda yapılan çalışmaların önemli bir bölümünde aracı kurum tavsiyelerinin hisse senedi fiyatları üzerinde özellikle kısa vadede etkili olduğu tespit edilmiştir. Bu çalışmaların bazılarında aracı kurum tavsiyelerinin hisse senedi fiyatı üzerinde duyuru sonrası oluşan fiyat baskısından kaynaklı kısa süreli bir fiyat hareketi oluşturduğu tespit edilirken, diğer çalışmalarda ise aracı kurum tavsiyelerinin bilgi içeriğinden dolayı duyuruların uzun vadeli etki yarattığı, başka bir ifadeyle duyuru sonrası ilgili hisse senetlerinde yeni bir fiyat dengesi oluştuğu gözlenmiştir. Son olarak bazı çalışmalarda ise kısa ya da uzun vadeli herhangi bir etkiye rastlanmamıştır. Her ne kadar bu çalışmaların önemli bir bölümü benzer veri setlerini içeren çalışmalar olsalar da, elde edilen sonuçların farklı olması piyasaların zaman içerisinde etkinliğinin değişebileceğini göstermektedir. Son yıllarda aracı kurum tavsiyelerinin hisse senedi fiyatlarına olan etkisi üzerine Türkiye'de herhangi bir çalışmaya rastlanmamıştır. Özellikle 2002 sonrası artan yabancı sermaye girişi ve gelişen menkul kıymetler borsası, aracı kurum tavsiyelerinin hisse senedi fiyatları üzerinde olan etkisinin ve aynı zamanda piyasa etkinliğinin günümüz koşullarında yeniden incelenmesini gerekli kılmaktadır. Bu çalışmada da 2007-2015 yılları arası İş Yatırım aracı kurumunun yatırım tavsiyelerinin hisse senedi fiyatlarına olan etkisi incelenmektedir. 
Yapılan olay çalışması analizi sonucunda, yatırımcıların olumlu ve olumsuz haberlere anlamlı tepki verdiği tespit edilmiştir. Başka bir ifadeyle, önerilen hisse senedi listesine giren şirketler pozitif anormal getiri elde ederken bu listeden çıkan hisse senetleri için ise piyasa duyuruya olumsuz tepki vermiş̧tir. Aracı kurumun oluşturduğu diğer bir öneri grubu da önerilmeyen hisse senedi listesidir. Bu listeye dahil olan hisse senetlerinin fiyatlarında olay sonrası anlamlı bir düşüş gözlenirken, bu listeden çıkan hisse senetleri ile ilgili olarak ise herhangi bir anlamlı tepki gözlenmemiştir. Bu durum, her ne kadar piyasanın olumlu veya olumsuz haberlere anlamlı tepkiler verdiğini gösterirken, olumsuz bir haberin ortadan kalkmasına (önerilmeyen hisse senedi listesinden çıkma) ise herhangi bir tepki vermediği sonucunu doğurmuştur. Sonuç olarak elde edilen bulgular genel olarak değerlendirildiğinde, aracı kurum tavsiyelerinin hisse senedi fiyatları üzerinde kısa vadede etkili olduğu, duyuru sonrası 15 günlük süre zarfinda duyuru öncesi fiyat seviyelerine bir geri dönüş olmadığı ve son olarak piyasanın yarı güçlü formda etkin olmadığı tespit edilmiştir. Bu sonuç Türkiye'de önceki yıllarda yapılan çalışmaların (Karan ve Ressamoğlu, 1996; Yazıcı ve Muradoğlu, 2002) bulgularından farklı olsa da, literatürdeki birçok çalışma sonucuyla paraleldir. Sonraki çalışmalarda veri seti genişletilerek ve diğer aracı kurumların tavsiyeleri de analize dahil edilerek çalışmadan elde edilen sonuçlar geliştirilebilir. Ayrıca, çalışmanın amacı aracı kurumların performans değerlendirmesi olmadığ uzun vadeli performansı kapsam dışında bırakılmıştır. Sonraki çalışmalarda aracı kurum portföylerinin uzun vadeli performansları incelenerek piyasa etkinliği ile ilgili elde edilen sonuçlar genişletilebilir.

\section{KAYNAKLAR}

Albert Jr., Robert L. - Smaby, Timothy R. (1997). "Market response to analyst recommendations in the "dartboard" column: the information and price-pressure effects", Review of Financial Economics, Vol. 5, No. 1, pp. 59-74.

Antweiler, Werner, - Frank, Murray Z. (2006). "Do US stock markets typically overreact to corporate news stories?". Available at SSRN 878091.

Barber, Brad - Lehavy, Reuven - McNichols, Maureen - Trueman, Brett. (2001). "Can investors profit from the prophets? Security analyst recommendations and stock returns". The Journal of Finance, Vol. 56, No. 2, pp. 531-563.

Barber, Brad M. - Loeffler, Dougles. (1993). "The "Dartboard" column: Second-hand information and price pressure". Journal of Financial and Quantitative Analysis, Vol. 28, No. 02, pp. 273-284.

Bjerring, James H. - Lakonishok, Josef - Vermaelen, Theo (1983). "Stock prices and financial analysts' recommendations". The Journal of Finance, Vol. 38, No. 1, pp. 187-204. 
Davies, Peter Lloyd - Canes, Michael (1978). "Stock prices and the publication of second-hand information”. Journal of Business, Vol. 51, No. 1, pp. 43-56.

Desai, Hemang - Jain, Prem C. (1995). "An analysis of the recommendations of the "superstar" money managers at Barron's annual roundtable". The Journal of Finance, Vol. 50, No. 4, pp. 1257-1273.

Dewally, Michael (2003). "Internet investment advice: Investing with a rock of salt”. Financial Analysts Journal, Vol. 59, No. 4, pp. 65-77.

Fama, Eugene F. (1991). "Efficient capital markets: II". The Journal of Finance, Vol. 46, No. 5, pp. 1575-1617.

Groth, John C. - Lewellen, Wilbur G. - Schlarbaum, Gary G. - Lease, Ronald C. (1979). "An analysis of brokerage house securities recommendations". Financial Analysts Journal, Vol. 35, No. 1, pp. 32-40.

Jegadeesh, Narasimhan - Kim, Woojin (2006). "Value of analyst recommendations: International evidence". Journal of Financial Markets, Vol. 9, No. 3, pp. 274309.

Karan, Mehmet B. - Ressamoğlu, Yaprak (1996), "Haftalık borsa dergilerindeki görüşlerin hisse senetleri performanslarına etkileri”, Hacettepe Üniversitesi İktisadi ve İdari Fakülteler Dergisi, Cilt. 14, Sayı. 2, pp. 121

Kerl, Alexander G. - Walter, Andreas (2007). "Market responses to buy recommendations issued by personal finance magazines: effects of information, price-pressure, and company characteristics". Review of Finance, Vol. 11, No. 1, pp. 117-141.

Kothari, S. P., - Warner, Jerold B. (2004). "The econometrics of event studies". Available at SSRN 608601.

Liang, Bing (1999). "Price Pressure: Evidence from the "Dartboard" Column". The Journal of Business, Vol. 72, No. 1, pp. 119-134.

Lidén, Erik R. (2006). "Stock Recommendations in Swedish Printed Media: Leading or Misleading?". The European Journal of Finance, Vol. 12, No. 8, pp. 731-748.

Lim, Tiong Kiong - Kong, Hwee Chi (2004). "New evidence on price impact of analyst forecast revisions". International Review of Financial Analysis, Vol. 13, No. 2, pp. 161-190.

Metrick, Andrew (1999). "Performance evaluation with transactions data: The stock selection of investment newsletters". The Journal of Finance, Vol. 54, No. 5, pp. 1743-1775.

Moshirian, Fariborz - Ng, David - Wu, Eliza (2009). "The value of stock analysts' recommendations: Evidence from emerging markets". International Review of Financial Analysis, Vol. 18, No. 1, pp. 74-83. 
Sant, Rajiv - Zaman, Mir A. (1996). "Market reaction to Business Week 'Inside Wall Street'column: a self-fulfilling prophecy". Journal of Banking \& Finance, Vol. 20, No. 4, pp. 617-643.

Yazici, Bilgehan - Muradoglu, Gülnur (2002). "Dissemination of stock recommendations and small investors: Who benefits?". Multinational Finance Journal, Vol. 6, No. 1, pp. 29-42.

Womack, Kent L. (1996). "Do brokerage analysts' recommendations have investment value?”. The Journal of Finance, Vol. 51, No. 1, pp. 137-167. 